\title{
Correction to: Prepared for PrEP: preferences for HIV pre-exposure prophylaxis among Chinese men who have sex with men in an online national survey
}

Wenting Huang ${ }^{1}$, Dan Wu ${ }^{1}$, Jason J. Ong ${ }^{2,3}$, M. Kumi Smith ${ }^{4}$, Stephen Pan ${ }^{7}$, Fan Yang ${ }^{1}$, Hongyun Fu ${ }^{1,5}$, Weiming Tang ${ }^{1,6}$ and Joseph D. Tucker ${ }^{1,3,8^{*}}$

Correction to: BMC Infect Dis (2019) 19:1057 https://doi.org/10.1186/s12879-019-4692-x

After publication of the original article [1], the authors would like to add a co-author, Dr. Stephen Pan, who contributed sufficiently to this manuscript. He was not included in the original article due to a miscommunication.

\begin{abstract}
Author details
'University of North Carolina at Chapel Hill Project-China, Guangzhou, China. ${ }^{2}$ Population Health Science, Bristol Medical School, University of Bristol, Bristol, UK. ${ }^{3}$ London School of Hygiene and Tropical Medicine, London, UK. ${ }^{4}$ Division of Epidemiology and Community Health, University of Minnesota Twin Cities, Twin Cities, USA. ${ }^{5}$ Eastern Virginia Medical School, Norfolk, USA. ${ }^{6}$ Dermatology Hospital, Southern Medical University, Guangzhou, China. ${ }^{7}$ Xi'an Jiaotong-Liverpool University, Wuzhong District, Suzhou, China. ${ }^{8}$ School of Medicine, University of North Carolina at Chapel Hill, Chapel Hill, NC 27599, USA.
\end{abstract}

\section{-}

\section{Reference}

1. Huang W, et al. Prepared for PrEP: preferences for HIV pre-exposure prophylaxis among Chinese men who have sex with men in an online national survey. BMC Infect Dis. 2019;19:1057. https://doi.org/10.1186/ s12879-019-4692-X.

The original article can be found online at https://doi.org/10.1186/s12879019-4692-x

* Correspondence: jdtucker@med.unc.edu

${ }^{1}$ University of North Carolina at Chapel Hill Project-China, Guangzhou, China

${ }^{3}$ London School of Hygiene and Tropical Medicine, London, UK

Full list of author information is available at the end of the article

(c) The Author(s). 2020 Open Access This article is licensed under a Creative Commons Attribution 4.0 International License, which permits use, sharing, adaptation, distribution and reproduction in any medium or format, as long as you give appropriate credit to the original author(s) and the source, provide a link to the Creative Commons licence, and indicate if changes were made. The images or other third party material in this article are included in the article's Creative Commons licence, unless indicated otherwise in a credit line to the material. If material is not included in the article's Creative Commons licence and your intended use is not permitted by statutory regulation or exceeds the permitted use, you will need to obtain permission directly from the copyright holder. To view a copy of this licence, visit http://creativecommons.org/licenses/by/4.0/ The Creative Commons Public Domain Dedication waiver (http://creativecommons.org/publicdomain/zero/1.0/) applies to the data made available in this article, unless otherwise stated in a credit line to the data. 